\title{
Methylmercury in tailings ponds of Amazonian gold mines (French Guiana): Field observations and an experimental flocculation method for in situ remediation
}

\author{
Stephane Guedron ${ }^{a_{1}}{ }^{*}$, Daniel Cossa ${ }^{b}$, Michel Grimaldi $^{c}$ and Laurent Charlet ${ }^{a}$
}

\author{
${ }^{a}$ IRD - Institut des sciences de la Terre (ISTerre) - UMR 5559 (IRD/UJF/CNRS) - University Joseph Fourier, \\ BP 53, F-3804 Grenoble, France \\ ${ }^{\mathrm{b}}$ IFREMER, Centre de Méditerranée, BP 330, F-83507 La Seyne-sur-mer, France \\ c IRD - UMR Bioemco-Biogéochimie et Ecologie des Milieux Continentaux, UMR211, 32 Avenue Henri Varagnat, \\ F-93143 Bondy, France
}

\begin{abstract}
*: Corresponding author : Stéphane Guedron, Tel.: +33 4766359 28, fax: + 33476635252 , +16 233790329 , email address : Stephane.Guedron@obs.ujf-grenoble.fr
\end{abstract}

\begin{abstract}
:
Sites of monomethylmercury ( $\mathrm{MMHg}$ ) production in Amazonian regions have been identified in hydraulic reservoirs, lake sediments and wetlands, but tailings ponds have not yet received sufficient attention for this purpose. This work evidenced high MMHg production within the water column and the interstitial water of two tailings ponds of French Guiana Au mines located; (i) in a small scale exploitation (Combat) where $\mathrm{Hg}$ was used for Au amalgamation, and (ii) in an industrial on-going $\mathrm{Au}$ mine (Yaoni) processing without $\mathrm{Hg}$. The $(\mathrm{MMHg})_{\mathrm{D}}$ maximum $\left(2.5 \mathrm{ng} \mathrm{L}^{-1}\right)$ occurred in the oxic water column above the sediment-water interface (SWI) of the most recent tailings pond (Combat), where the substrate was fresh, the redox transition was sharp and the pool of total $\mathrm{Hg}$ was large. In the Yaoni pond, the $(\mathrm{MMHg})_{\triangleright}$ maximum concentration $\left(1.4 \mathrm{ng} \mathrm{L}^{-1}\right)$ was located at the SWI where suboxic conditions prevailed. Using the $(\mathrm{MMHg})_{D}$ concentration as a proxy for $\mathrm{Hg}$ methylation rates, the present results show that $\mathrm{Hg}$ methylation may occur in various redox conditions in tailings ponds, and are favored in areas where the organic matter regeneration is more active.
\end{abstract}

A 3-month long laboratory experiment was performed in oxic and anoxic boxes filled with high turbidity waters from the Combat Au mine to simulate tailings ponds. Slaked lime was added in an experimental set $\left(2 \mathrm{mg} \mathrm{L}^{-1}\right)$ and appeared to be very efficient for the reduction of suspended particulate matter (SPM) to environmentally acceptable concentrations. However, at the end of the experiment, large $(\mathrm{MMHg})_{\mathrm{D}}$ concentrations were monitored under treated anoxic conditions with the $(\mathrm{MMHg})_{\mathrm{D}}$ maximum located at the SWI above the Fe-reducing zones. No $(\mathrm{MMHg})_{\mathrm{D}}$ was detected in oxic experiments. The use of slaked lime for SPM decantation appears to be an efficient and nononerous process for Au miners to avoid $\mathrm{Hg}$ methylation in tailings ponds when it is combined with rapid drainage of the mine waters. A subsequent human intervention is however necessary for the recovery of soil structure through the cover of dried ponds with organic rich materials and reforestation to avoid the stagnation of rain waters and the occurrence of anoxia. 


\section{Research highlights :}

Two tailings ponds of French Guiana Au mines were studied. High monomethylmercury (MMHg) production was found within water column and interstitial water. A laboratory experiment simulating tailings ponds was performed in oxic and anoxic conditions. Slaked lime addition decreased suspended particles but not MMHg concentrations. - Remediation must consider decantation, ponds drainage and reforestation to limit $\mathrm{Hg}$ methylation.

Key-words : Mercury, Methylmercury, Gold placers, Tailing ponds, Remediation 


\section{Introduction}

Gold mining activities, located mostly in tropical regions, are responsible for more than $10 \%$ of global mercury emissions (Smodis, 2006). The local ecological concern of this anthropogenic input depends mainly on the sites and the rate of $\mathrm{Hg}$ transformation into its toxic methylated species, and its transfer and bioamplification as monomethylmercury ( $\mathrm{MMHg}$ ) in the aquatic food chains (Akagi et al., 1995; Boudou et al., 2005; Carmouze et al., 2001; Dolbec et al., 2000; Frery et al., 2001; Pfeiffer et al., 1993; Veiga et al., 1999; Watras, 1992; Watras et al., 1994). This process and the associated toxicological concerns for inhabitants, whose diet relies on fish, have been evidenced in the Amazon plain and the Guyana plateau by many authors (Akagi et al., 1995; Carmouze et al., 2001; Dolbec et al., 2000; Frery et al., 2001). Sites of MMHg production in these regions have been commonly identified in hydraulic reservoirs, lake sediments and wetlands (Coquery et al., 2003; Dominique et al., 2007; Guimaraes et al., 2000a; Guimaraes et al., 2000b; Kehrig et al., 2003; Roulet et al., 2001a). Most of these sites constitute biogeochemical reactors with sharp redox transitions and where large concentrations of electron acceptors (dissolved organic matter (OM), sulfates, and iron oxides) favor bacterial activity (Fitzgerald and Lamborg, 2003; Fleming et al., 2006; Lamborg et al., 2008; Muresan et al., 2008; Ullrich et al., 2001)

Alluvial gold mining activities, using elemental $\mathrm{Hg}$ for $\mathrm{Au}-\mathrm{Hg}$ amalgamation, have been highlighted to be the major source of $\mathrm{Hg}$ for tropical environments during $\mathrm{Au}-\mathrm{Hg}$ amalgamation and the burning of amalgams (Lacerda and Salomons, 1998). In addition, the release of large suspended particles, when soils are flushed to take off light particles for the concentration of heavy gold-rich fractions, is also an important diffusive source of $\mathrm{Hg}$ for downstream hydrosystems (Lacerda, 1997; Roulet et al., 
2001b). Indeed, these suspended particles have high $\mathrm{Hg}$ concentration since they accumulate $\mathrm{Hg}$ from long term in situ weathering of rock, natural and recent industrial atmospheric emissions (Baeyens et al., 1991; Guedron et al., 2006; Schroeder and Munthe, 1998). To avoid downstream river contamination, environmental policy requires that gold-miners concentrate mine tailings into tailing ponds for particle sedimentation. Such tailing ponds are comparable to small-scale hydraulic reservoirs since sediment stratification occurs and redox gradients can establish rapidly. Recently, several authors pointed out high methylmercury levels in Au and $\mathrm{Hg}$ mine tailings, which indicated that methylation of metallic $\mathrm{Hg}$ in the tailings can occur at significant levels, consistently with the identification of sulfate-reducing bacteria (SRB) in the same type of environments (Gray et al., 2004; Gray et al., 2006; Ikingura et al., 2006; Winch et al., 2008). However, no information is available on the possible occurrence of $\mathrm{Hg}$ methylation in tailing ponds themselves. In French Guiana environments, the high density of clay particles associated with $\mathrm{OM}, \mathrm{Fe}$ or $\mathrm{Al}$ oxides (Do Nascimento et al., 2004; Guedron et al., 2006; Roulet and Lucotte, 1995) and combined with elevated temperatures $\left(25-35^{\circ} \mathrm{C}\right)$ and a cidic $\mathrm{pH}(4-5)$ (Barret, 2004) favor geochemical conditions and nutrient stocks propitious for mercury bacterial methylation (Ullrich et al., 2001). Here we address the question of the location and significance of mercury methylation in mine tailing ponds from two French Guiana gold mines, the Combat and Yaoni mines, and we test the efficiency of a common waste water flocculent (slaked lime) for particles decantation and its associated impact on mercury methylation.

\section{Sites, material and methods}

\subsection{Environmental settings}


Two tailing ponds were monitored on different gold mines located in French Guyana, a region where the climate is tropical with an annual average rainfall of 4000 mm (Barret, 2004).

The first tailing pond (Combat) is located on a former goldmine site $\left(5223^{\prime} \mathrm{W}\right.$, $44^{\circ} \mathrm{N}$ ), which was exploited at the beginning of the 1950's by artisanal gold miners who used $\mathrm{Hg}$ for gold amalgamation (Fig. 1). Macroscopic $\mathrm{Hg}$ droplets were identified in these gold mined hydromorphic soils (Guedron et al., 2009). This mine is located on the 'Amina series' of the Guiana Proterozoic shield consisting primarily of dark schist facies and thin sandstones (Egal et al., 1994). This site has recently been exploited for a second time by the CMB (Boulanger Mining Company). During the exploitation, an experimental pond of $10 \mathrm{~m}$ long, $8 \mathrm{~m}$ wide and 1 to $2 \mathrm{~m}$ deep was dug and filled with mine water ( $\mathrm{pH} 4$ to 5) of around $0.1 \mathrm{~g} \mathrm{~L}^{-1}$ suspended particulate matter (SPM) load. The mean total $\mathrm{Hg}$ concentration of the SPM was $0.90 \mu \mathrm{g} \mathrm{g}{ }^{-1}$. The Combat pond was monitored during December 2006, 6 months after its filling.

The second tailing pond (Yaoni) is located on the Coralie track, in the Yaoni placer $\left(524^{\prime} \mathrm{W}, 4^{\circ} 1^{\prime} \mathrm{N}\right)$, which is a large alluvial gold $\mathrm{m}$ ine of the CMB still in exploitation (Fig. 1). This mine is located on the 'Paramaca formation' of the Guiana proterozoic shield consisting of metavolcanic rocks (Egal et al., 1994). Gold is exploited by gravimetric methods using a shaking table to segregate gold from ore sands. The tailing pond was monitored during December 2006, two years after its filling. The pond dimensions were $300 \mathrm{~m}$ long, $100 \mathrm{~m}$ wide, 1.4 to $5 \mathrm{~m}$ deep. The water $\mathrm{pH}$ ranged between 4 and 5 , the SPM load was $3.3 \mathrm{~g} \mathrm{~L}^{-1}$, and the mean total $\mathrm{Hg}$ concentration of the SPM was $0.50 \mu \mathrm{g} \mathrm{g}^{-1}$.

\subsection{Sampling procedure}


Field and laboratory sample collection and treatment were performed using ultraclean techniques (Cossa and Gobeil, 2000) and analytical methods applied for water analyses. All materials in contact with samples were acid-washed (5 days in $20 \%$ $\mathrm{HNO}_{3} \mathrm{v} / \mathrm{v}$, then 3 days in $\mathrm{HCl} 10 \% \mathrm{v} / \mathrm{v}$ ) and rinsed several times with demineralized water (Milli- $Q^{\circledR}$ ) before use. Polyethylene gloves were used for handling operations. Clean Teflon ${ }^{\circledR}$ (FEP) bottles were stored in double polyethylene bags until use. Acid washed peepers were degassed in a proof box during 15 days with Hg-free Ar. They were then disposed during 15 days in the tailing ponds and 3 months for the laboratory experiments. Interstitial water was extracted immediately after sampling by tipping water in the peeper cells. The sulfide-accumulating zone (SAZ) was identified with sulfide sensitive sellotape, through the formation of a surface darkening Ti-S complex (Jezequel et al., 2007). Superficial pond water samples were collected by PE-gloved-hand in Teflon ${ }^{\circledR}$ (FEP) bottles which were three times rinsed with the pond water at each sampling site prior to the sample collection. Aliquots for dissolved methyl mercury $\left((\mathrm{MMHg})_{\mathrm{D}}\right)$ where filtered with Sterivex ${ }^{\circledR}-\mathrm{HV} 0.45 \mu \mathrm{m}$ sterile filters in the field. After the first $50 \mathrm{~mL}$ had been discarded, the filtrates were collected in Teflon $^{\circledR}$ (FEP) bottles (rinsed beforehand several times with filtrate), acidified ( $\mathrm{HCl} 0.5$ $\% \mathrm{v} / \mathrm{v}$, Seastar $^{\circledR}$ ) and kept in two polyethylene (PE) bags until analysis. In addition to samples for $\mathrm{Hg}$ speciation analyses, aliquot samples were collected to determine the concentration of constituent sulfides, and reduced iron. After the first $10 \mathrm{~mL}$ had been discarded, the filtrates were collected in Pyrex ${ }^{\circledR}$ glass bottles, rinsed beforehand several times with filtrate and analyzed in the field.

\subsection{Laboratory experiments}

Stream waters were sampled in the Combat creek within $2 \mathrm{~L} \mathrm{Teflon}{ }^{\oplus}(\mathrm{FEP})$ bottles using ultra clean techniques and frozen before use. Around $4 \mathrm{~kg}$ of soil samples were 
collected from the Combat gold mine, several meters from the monitored Combat decantation pond to have similar material as in the field measurements. Collected soils were identified as the mineral horizon of a contaminated hydromorphic soil of the Combat gold mining flat.

Two boxes each containing four separated compartments of $33 \mathrm{~cm}$ height, $8 \mathrm{~cm}$ width and $20 \mathrm{~cm}$ length were filled with stream waters sampled in the Combat stream mixed with $2 \pm 0.1 \mathrm{~kg}$ of soil sample. Chemical grade $\mathrm{Ca}(\mathrm{OH})_{2}$ (slaked lime) was added $\left(2 \mathrm{mg} \mathrm{L}^{-1}\right)$ to the first box, with 2 compartments set in open-air (oxic compartments $\mathrm{F} 1 \mathrm{O}$ and $\mathrm{F} 2 \mathrm{O}$ ) and two sealed compartments degassed with $\mathrm{Hg}$-free $\mathrm{N}_{2}$ (anoxic compartments $\mathrm{F} 1 \mathrm{~A}$ and $\mathrm{F} 1 \mathrm{~B}$ ). The second box was used for controls in the same conditions without slaked lime ( $\mathrm{C} 1 \mathrm{O}$ and $\mathrm{C} 2 \mathrm{O}$ for oxic compartments and C1A and C2A for anoxic compartments). A peeper was placed in each compartment. The atmosphere above the water in the sealed compartments was renewed with a low flux of $\mathrm{Hg}$-free $\mathrm{N}_{2}$. Both boxes were wrapped with aluminium foil to limit light penetration and algae formation, and set at room temperature $\left(25 \pm 2^{\circ} \mathrm{C}\right)$ during $\sim 3$ months (103 days). $\mathrm{pH}$ and conductivity were followed only in the open-air compartments during the experiment time. These measurements were performed in anoxic compartments at the beginning and the end of experiment to avoid the introduction of $\mathrm{O}_{2}$.

\subsection{Analytical measurements}

Samples were analyzed for $\left[(\mathrm{MMHg})_{D}\right]$ by cold vapor atomic fluorescence spectrometry (CVAFS) after conversion of all mercury species into $\mathrm{Hg}^{0}$ (Bloom and Fitzgerald, 1988), using a $\operatorname{Tekran}^{\circledR}$ (Model 2500) mercury detector. For (MMHg) determination we used the hydruration method described by (Tseng et al., 1998), modified by Cossa et al. (2009). These quantifications were performed after checking 
for possible interference with internal spikes (Coquery et al., 2003). The accuracy was checked using a certified reference material (CRM) ERM-AE670 (IRMM European Commission). The detection limit, defined as 3 times the standard deviation of the blanks $\left(\mathrm{SD}_{\mathrm{blk}}\right)$, was $0.01 \mathrm{ng} \mathrm{L}^{-1}$. The reproducibility varied from $10 \%$ to $15 \%$ according to the concentration level.

Total particulate mercury $(\mathrm{HgT})_{\mathrm{P}}$ was determined by cold vapor atomic absorption spectrometry after thermal decomposition of the sample using an automatic solid analyzer (Altec $\AA$, model AMA-254). The detailed procedure is described elsewhere (Cossa et al., 2003; Cossa et al., 2002). The detection limit ( 3 SD blk $)$ was $0.005 \mathrm{mg}$ $\mathrm{kg}^{-1}$ and the reproducibility better than $5 \%$. The method is known as the standard method $N^{\circ} 7473$ of the US-EPA. The accuracy of the determination for $(\mathrm{HgT})_{\mathrm{P}}$ concentrations were estimated using CRM 7002 (Czech Metrological Institute); the repeated analyses never exceeded the published concentration ranges $(0.090 \pm$ $\left.0.012 \mu g^{-1}\right)$.

Dissolved reduced iron (Fe") and sulfide ( $\left.\mathrm{S}^{\prime \prime}\right)$ concentrations were measured in the field with a $\mathrm{Hach}^{\circledR}($ model DR/850) colorimeter (methods 8146 and 8131 for Fe" and $\mathrm{S}^{\prime \prime}$, respectively). Detection limits $\left(3 \mathrm{SD}_{\mathrm{blk}}\right)$ were $0.01 \mathrm{mg} \mathrm{L}^{-1}$ for both $\mathrm{Fe}^{\prime \prime}$ and $\mathrm{S}^{\prime \prime}$ concentration measurements.

Eh, $\mathrm{pH}$ and conductivity profiles were performed in situ using a Sentron ${ }^{\circledR}$ Eh meter (model Argus with probe 67597), a Heito ${ }^{\circledR} \mathrm{pH}$ meter (model, PPD 26) and a WTW ${ }^{\circledR}$ conductimeter (model 340i), respectively.

\section{Results and discussion}

\subsection{Mercury methylation in tailing ponds - field measurements}


Dissolved $\mathrm{MMHg}$ concentrations were larger in the Combat tailing pond than in the Yaoni pond (Mean \pm SD $=1.02 \pm 0.74$ and $0.24 \pm 0.50 \mathrm{ng} \mathrm{L}^{-1}$, range $=0.27$ to 2.53 and 0.01 to 1.44 , respectively - Fig. 2). [(MMHg $\left.)_{D}\right]$ in both ponds were in the range of concentrations reported in the hypolimnion waters of Petit Saut reservoir, Sinnamary basin in French Guiana (0.06 to $1.19 \mathrm{ng} \mathrm{L^{-1 }}$ - (Muresan, 2006). In both ponds, the sulfide accumulation zones (SAZ) were identified from the sediment-water interface (SWI) to the deep sediments in both profiles (Fig. 2). $S^{\prime \prime}$ concentration measured in the field (data not shown) superimposed very well to the identified SAZ for both ponds, but concentrations were low, often close to detection limit of the method, ranging between 0.01 to $0.03 \mathrm{mg} \mathrm{L}^{-1}$ with weak variation with depth.

The most striking features for the $\left[(\mathrm{MMHg})_{D}\right]$ vertical distributions were (i) the elevated concentrations in the water column especially in surface waters (0.92 and $0.32 \mathrm{ng} \mathrm{L}^{-1}$, for Combat and Yaoni respectively) and (ii) the fact that they exceeded concentrations monitored in the sediment pore waters. The occurrence of maximum $(\mathrm{MMHg})_{D}$ concentrations located above and at the SWI for Combat $\left(2.5 \mathrm{ng} \mathrm{L}^{-1}\right)$ and Yaoni (1.4 $\mathrm{ng} \mathrm{L}^{-1}$ ) pond respectively, indicates a source (production) of MMHg. In addition, these $(\mathrm{MMHg})_{D}$ peaks were located above the SAZ associated within high Eh and slightly negative Eh for Combat and Yaoni ponds respectively (Fig. 2). In the case of the Combat pond, methylmercury peaks occurred well above the ferrireduction zone, and consequently above the sulfate-reducing one. The occurrence of a $(\mathrm{MMHg})_{D}$ maximum in hypoxic environment above the SWI has previously been described in marine lagoon sediments by Muresan et al. (2007). These observations suggest that the main methylation can occur disconnected from ferri-reducing bacteria (FRB) or SRB main activity sites, which are below the SWI (Fig. 2). This distribution pattern is consistent with the recent findings of active mercury 
methylation in the oxygenated water columns of the open ocean (Cossa et al., 2009; Sunderland et al., 2009). Inorganic mercury methylation in hypoxic aquatic environment, even if the mechanism for this (these) reaction(s) are still unknown, may occur in "micro-niches" sheltering suboxic environments (Amouroux et al., 2009; Lin and Jay, 2007). The large particulate load is suggestively a great carrier for bacterial metabolism and thus for methylation in the water column, since they are mainly composed of clay size organic matter and $\mathrm{Fe}$ or Al oxides which are the main carrier for $\mathrm{Hg}$ in tropical soils (Guedron et al., 2009).

In the Combat tailing pond, a second peak $\left(0.8 \mathrm{ng} \mathrm{L}^{-1}\right)$ was monitored in the sediment pore water around $-15 \mathrm{~cm}$ (Fig. 2). The occurrence of this secondary peak in the reducing $\mathrm{SAZ}$ and below the $\mathrm{Fe}{ }^{\|}$peak $(-4 \mathrm{~cm}$, Fig. 2) suggests that $\mathrm{Hg}$ methylation is likely due to FRB or SRB. This feature is similar to numerous observations in aquatic sediment (i.e., (Benoit et al., 1999; Lamborg et al., 2008) and suggests an optimum sulfide concentration favoring in situ methylation. This hypothesis is consistent with the theory according to which the bioavailability of inorganic mercury for SRB methylation is controlled by the presence of neutral $\mathrm{Hg}-\mathrm{S}$ complexes (Benoit et al., 2003; Benoit et al., 2001). According to Muresan et al. (2007), this also suggests that the sub-surface peak monitored in the Yaoni pond at the $S W I$ results from the $(\mathrm{MMHg})_{D}$ diffusion from the sediment interior, where SRB are active, which is trapped by oxides at the very top of the sediment surface layer.

The difference in $(\mathrm{MMHg})_{D}$ distribution between the two vertical profiles as well as the larger $(\mathrm{MMHg})_{D}$ production in the Combat relative to the Yaoni tailing pond can be attributed to the different age and composition of the two substrates leading to a more active OM oxidation in the Combat pond. First, it can be argued that the Combat pond is the most recent and is richer in fresh substrate (including OM) 
251 favoring bacteria activity. Second, the sediment consolidation and stratification is also

252 less established than in the Yaoni pond facilitating water diffusion and advection.

253 These remarks are supported by the sharp Eh transition above the SWI in the Combat pond in comparison to the progressive Eh transition monitored in Yaoni (Fig. 2). Finally, according to the gold mining past of the Combat site (Guedron et al., 2009), the $\mathrm{Hg}$ enrichment of sediments and the presence of macroscopic droplets implies a larger $\mathrm{Hg}$ pool, which is potentially bioavailable for bacterial methylation (Dominique et al., 2007). In opposition the use of $\mathrm{Hg}$ in the Yaoni mine is restricted by the mining processes which do not use $\mathrm{Hg}$ for $\mathrm{Au}-\mathrm{Hg}$ amalgamation and the $\mathrm{Hg}$ is mainly related to geogenic and atmospheric origin.

\subsection{Effect of slaked lime addition on $\mathrm{Hg}$ methylation in experimental tailing ponds}

The results from the test of the effect on particle decantation with slaked lime addition $\left(2 \mathrm{mg} \mathrm{L}^{-1}\right)$ were very conclusive; the SPM concentration largely decreased from $320+/-40 \mathrm{mg} \mathrm{L}^{-1}$ to $27+/-5 \mathrm{mg} \mathrm{L}^{-1}$ only a few minutes after slaked lime addition. SPM values obtained after treatment were in the range of concentrations measured in the Combat Creek before the beginning of the goldmining activities (25 $\pm 16 \mathrm{mg} \mathrm{L}^{-1}-$ unpublished data) and of reported concentrations for three French Guiana creeks un-impacted by goldmining activities $\left(5-38 \mathrm{mg} \mathrm{L}^{-1}-\right.$ Muresan et al., (2008).

As expected, the slaked lime treatment induced a significant change in the chemical conditions in the experimental boxes. In the treated compartments (F10, $\mathrm{F} 20$, FIA and F2A), $\mathrm{pH}$ reached nearby 11 at the beginning of the experiment, while the untreated sediment slurry was between 4 and 5 (C10, C20, C1A and C2A). Figure 3 illustrates the progressive chemical stabilization of soil particles with water 
during the three months of experimentation in the "open air" compartments. In both control compartments (i.e., $\mathrm{C} 1 \mathrm{O}$ and $\mathrm{C} 2 \mathrm{O}$ ), the $\mathrm{pH}$ progressively increased by about $1 \mathrm{pH}$ unit over the first 60 days then stabilized, while conductivity slightly decreased. In contrast, in both experimental compartments where slaked lime was added (i.e., $\mathrm{F} 1 \mathrm{O}$ and F2O), a sharp decrease of $\mathrm{pH}$ (from 10.8 to 8 ) and conductivity (from 380 to 140) was monitored in the first days and even hours after flocculent addition (Fig. 3). Then, until the end of the experiment, $\mathrm{pH}$ progressively decreased to a stabilized value (7.7), while conductivity progressively increased during the same period from 130 to $\sim 180 \mu \mathrm{S} \mathrm{cm}^{-1}$. At the end of the experiment, $\mathrm{pH}$ and conductivity monitored in the water column of anoxic treated compartments were in the same range of oxic treated compartments. Eh measurements revealed an air leak in the two control compartments ( $1 \mathrm{~A}$ and $\mathrm{C} 2 \mathrm{~A})$, thus, the following results and discussion will not consider these two so-called anoxic control compartments.

Large $\left[(\mathrm{MMHg})_{\mathrm{D}}\right]$ were monitored in the two anoxic compartments (i.e., F1A and $\mathrm{F} 2 \mathrm{~A}$ ) where slaked lime was added (Mean $\pm \mathrm{SD}=0.65 \pm 0.84$ and $0.56 \pm 0.36 \mathrm{ng} \mathrm{L}^{-1}$, range $=0.002$ to 2.27 and 0.37 to 1.52 , respectively for F1A and F2A - Fig 4). Sulfides were not detectable for both anoxic compartments and Fe" concentration profiles exhibited very low concentrations $\left(<0.05 \mathrm{mg} \mathrm{L}^{-1}\right)$ in the water column and a sharp increase at the SWI to reach largest values in the sediment at $-4 \mathrm{~cm}$. $\left[(\mathrm{MMHg})_{D}\right]$ maxima in both $\mathrm{F} 1 \mathrm{~A}$ and $\mathrm{F} 2 \mathrm{~A}$ compartments were monitored on the SWI and were in the same range of $\left[(\mathrm{MMHg})_{D}\right]$ maxima measured in Yaoni and Combat ponds. Large $\left[(\mathrm{MMHg})_{D}\right]\left(\right.$ Mean $\pm S D=0.26 \pm 0.16$ and $0.46 \pm 0.07 \mathrm{ng} \mathrm{L}^{-1}$, respectively for $\mathrm{F} 1 \mathrm{~A}$ and $\mathrm{F} 2 \mathrm{~A}$ ) were also monitored in the water column at weak Eh values $(-90 \mathrm{mV})$. These large $\left[(\mathrm{MMHg})_{D}\right]$ in the water column may results from the desorption of $\mathrm{MMHg}$ form particles after slaked lime addition or from in situ 
methylation. In the beginning of the experiment, the increase in $\mathrm{pH}$ and conductivity resulting from the $\mathrm{Ca}(\mathrm{OH})_{2}$ dissolution may lead to aluminium oxide particle dissolution (Hind et al., 1999) and to the release of sorbed elements, including MMHg, from the particles surface through the water column. Such Al (hydr)oxides were identified in the field for the same soils as carrier phases for $\mathrm{Hg}$ (Guedron et al., 2009). Nevertheless, observations made in the oxic boxes are in contradiction with the hypothesis of $\mathrm{MMHg}$ release through the solution since no $(\mathrm{MMHg})_{D}$ was monitored in the water column of treated oxic boxes where similar desorption may have occur (Fig 5). Thus, the hypothesis of the in situ methylation is more probable and we can reasonably speculate that a larger accessibility of dissolved elements (e.g., DOC, sulfates, nitrates, etc.) after slaked lime treatment would be stimulating for bacteria metabolism and furthermore for methylation under suboxic conditions as observed in lake tropical water columns below the oxycline (Coquery et al., 2003). In addition, the occurrence of $(\mathrm{MMHg})_{D}$ peaks above the Fe" maxima and in absence of sulfides suggests a $\mathrm{Hg}$ methylation by FRB rather than SRB (Fig. 4). Nevertheless, the absence of controls under anoxic conditions limits this interpretation. The diffusion of $\mathrm{MMHg}$ in the water column from the sediment can also be suggested. Since laboratory measurements were done in the dark, the rates of demethylation are thus reduced in the water column since photodemethylation is impossible. In the field, demethylation would certainly be larger in the water column after slaked lime addition since the absence of particle could not limit UVB penetration.

In opposition to anoxic compartments, $\left[(\mathrm{MMHg})_{\mathrm{D}}\right]$ were very low and close to the detection limit in all "open-air" experiments with and without slaked lime addition (Fig 5). In parallel, Eh and Fe" concentration profiles didn't show any significant vertical pattern. Such oxic conditions are not propitious for bacterial methylation (Benoit et 
al., 2003). In addition, as discussed previously for the anoxic boxes, at $\mathrm{pH} 11$, aluminium oxide dissolution occurs, while iron(III) hydroxide do not (Hind et al., 1999; Schwertmann and Cornell, 2000). Then, when the solution reach the equilibrium ( $\mathrm{pH}$ 7.7), Al adsorbs on the various solid phases (Charlet et al., 1993) or Al- (hydr)oxides may re precipitate because of the low solubility of aluminium hydroxide below pH 9.5. The formation of such Fe and Al hydroxides, which are known to be great adsobants for dissolved $\mathrm{Hg}$ and $\mathrm{MMHg}$, may limit the presence of both $\mathrm{Hg}$ and $\mathrm{MMHg}$ in solution (Feyte, 2007).

\subsection{Good practices for remediation}

In opposition to field observation, $\mathrm{Hg}$ methylation under oxic conditions was not observed in laboratory experiment with and without addition of slaked lime even after 3 months of experiment. Based on these results, we can suggest that the methylation process under oxic conditions may be dependent on microbiological and geochemical parameters, which may have been modified in the lab experiments. Even if the production of $\mathrm{MMHg}$ under anoxic or suboxic conditions is evidenced in presence of slaked lime, the use of slaked lime as flocculent to enhance particles decantation rates have to be considered.

First, the rapid decrease of SPM after slaked lime addition to concentrations found in un-impacted creeks of French Guiana fits with the environmental policy requirements. Second, since the decantation yields are rapid, the drainage of decanted mine waters can also be done faster, allowing to avoid the formation of reducing conditions where $\mathrm{MMHg}$ production is the largest. In addition, since field observation showed that methylation occurred in the oxic water column, the particle decantation coupled with a rapid drainage of the pond may both increase 
photodemethylation by facilitating UVB penetration and limit $\mathrm{Hg}$ methylation in the water column by reducing water residence time.

Following the drainage of the ponds two aspects have to be considered. First, even if the chemical equilibrium of treated waters is rapid allowing a rapid drainage of the pond, the final $\mathrm{pH}$ of treated waters is 2 to $3 \mathrm{pH}$ units higher (7-8) than in stream waters (5). Thus, miners would have to dilute these treated waters with those of the mine diverted canals before it re-integers the main stream. Second, when the ponds are drained and dried, the surface compaction of thin particles limits vegetation growth and natural forest succession is effectively stalled (Bradshaw, 1997). In this case, tailing ponds are subject to be filled during intense rain event and/or to superficial erosion leading to the re-suspension of particles. Thus, the success of rehabilitation depends on human intervention to restore soil fertility, which comprises reconstitution of the physico-chemical characteristics of the soils and the recovery of biological functions (especially microbial ones - Schimann et al., 2007). Schimann et al., (2007) demonstrated that 8 years after the introduction of legumes in a gold mined site of French Guiana, microbial activities were similar to those of natural forested soils. Thus, the revegetation of ponds will increase soil drainage and limit the occurrence of anoxia in soil pore waters which maybe restrictive for $\mathrm{Hg}$ methylation.

To resume, the rehabilitation of a gold mined site must be done rapidly after the exploitation, by fast decantation with slaked lime, drainage of decanted waters and covering the dried pond with $\mathrm{OM}$ rich materials (e.g., organic horizons remove at the beginning of mining operations) and reforestation, to prevent $\mathrm{MMHg}$ production and particulate emission through superficial erosion. 


\section{Summary and conclusion}

Tailing ponds of industrial and small scale artisanal Amazonian gold mines can be assimilated to small scale biogeochemical reactors such as hydraulic reservoirs since similar geochemical conditions providing the occurrence of large dissolved methylmercury concentrations in both water column and sediment pore waters were evidenced in this study. The main feature in the comparison of both studied ponds is the large $(\mathrm{MMHg})_{D}$ concentrations measured under various redox conditions (i.e., anoxic, suboxic and (hyp)oxic conditions) in both sediment and water column of the recent Combat tailing pond. The age and the substratum quality of the ponds were shown to be major parameters for mercury methylation since fresh $\mathrm{OM}$, $\mathrm{Hg}$ content, sharp redox transitions enhance bacteria metabolism as much as methylating activities.

Laboratory experiments to test the efficiency of slaked lime addition on particles flocculation showed that the increase of decantation yield was rapid and efficient. No methylation occurred under oxic conditions, while large $(\mathrm{MMHg})_{\mathrm{D}}$ concentrations were measured under suboxic and anoxic conditions after slaked lime addition. It was concluded that the easiest way for gold miners to limit $\mathrm{Hg}$ methylation is to prevent the occurrence of reducing conditions by coupling decantation and drainage. The use of slaked lime appears to be a simple and not onerous solution in remediation process. The coupling of decantation, rapid drainage of the pond and human intervention to restore soil fertility, and reforest the site are the most effective processes to avoid $\mathrm{Hg}$ methylation during the mining activities.

\section{Acknowledgments}


399 This research was supported mainly by the CNRS as a part of the Mercury in 400 French Guiana research program and by the Boulanger Mine Company (CMB). We 401 also acknowledge Bernard Averty, Genlis Gallifet and Gwenael Cloarec for additional 402 support and help for the realization of this project. 
Akagi, H., Malm, O., Branches, F. G. P., Kinjo, Y., Kashima, Y., Guimara, J. R. D., Oliveira, R. B., Haraguchi, K., Pfeiffer, W. C., Takizava, Y., et al., 1995. Human exposure to mercury due to goldmining in the tapajos river basin, Amazon, Brazil: speciation of mercury in human hair, blood and urine. Water Air Soil Poll. 80, 85-94.

Amouroux, D., Monperrus, M., Tessier, E., Guyoneaud, R. Tracking the source and fate of methylated mercury species in the water column of the Mediterranean Sea. 9th International Conference on Mercury as a Global Pollutant. CAS, Guiyang (China), 2009.

Baeyens, W., Leermakers, H., Dedeurwaerder, H., Lansens, P., 1991. Modelization of the mercury fluxes at the air-sea interface. Water Air Soil poll. 56, 731-744.

Barret, J., 2004. Illustrated Atlas of French Guyana (in French). French Guyana Publications Cayenne.

Benoit, J. M., Gilmour, C. C., Heyes, A., Mason, R. P., Miller, C. L., 2003. Geochemical and biological controls over methylmercury production and degradation in aquatic ecosystems. In: Cai $\mathrm{Y}$, Braids $\mathrm{OC}$, eds, Biogeochemistry of Environmentally Important Trace Elements. 835. Oxford University Press, pp. 262-297

Benoit, J. M., Gilmour, C. C., Mason, R. P., 2001. Aspects of bioavailability of mercury for methylation in pure cultures of Desulfobulbus propionicus (1pr3). Appl. Environ. Microbiol. 67, 51-58.

Benoit, J. M., Gilmour, C. C., Mason, R. P., Heyes, A., 1999. Sulfide controls on mercury speciation and bioavailability to methylating bacteria in sediment pore waters. Environ. Sci. Technol. 33, 951-957.

Bloom, N. S., Fitzgerald, W. F., 1988. Determination of volatil mercury spices at the picogram level by low-temperature gas chromatography with cold-vapor atomic fluorescence detection. Anal. Chim. Acta 208, 151-161.

Boudou, A., Maury-Brachet, R., Coquery, M., Durrieu, G., Cossa, D., 2005. Synergic Effect of Gold Mining and Damming on Mercury Contamination in Fish. Environ. Sci. Technol. 39, 2448-2454.

Bradshaw, A., 1997. Restoration of mined lands - using natural processes. Ecological Engineering 8, 255-269.

Carmouze, J. P., Lucotte, M., Boudou, A., 2001. Mercury in the Amazon. Human and environmental implications, health risks. Bondy (in French).

Charlet, L., Schindler, P. W., Spadini, L., Furrer, G., Zysset, M., 1993. Cation adsorption on oxides and clays: The aluminum case. Aquatic Sci. 55, 291-303.

Coquery, M., Cossa, D., Azemard, S., Peretyazhko, T., Charlet, L., 2003. Methylmercury formation in the anoxic waters of the Petit-Saut reservoir (French Guiana) and its spreading in the adjacent Sinnamary river. J. Phys. IV 107, 327-331.

Cossa, D., Averty, B., Bretaudeau, J., Senard, A. S., 2003. Dissolved mercury speciation in marine waters. Analysis methods in marine environment. Ifremer and French Ecology, Durable Development Ministry (in French).

Cossa, D., Averty, B., Pirrone, N., 2009. The origin of methylmercury in open Mediterranean waters. Limnol. Oceanogr. 54, 837-844.

Cossa, D., Coquery, M., Nakhle, K., Claisse, D., 2002. Total mercury and monomethylmercury analysis in marine organisms and sediments. Analysis 
methods in marine environment. Ifremer and French Ecology, Durable Development Ministry (in French).

Cossa, D., Gobeil, C., 2000. Mercury speciation in the Lower St. Lawrence estuary. Can. J. Fish. Aquat. Sci. 57, 138-147.

Do Nascimento, N. R., Bueno, G. T., Fritsch, E., Herbillon, A. J., Allard, T., Melfi, A. J., Astolfo, R., Boucher, H., Li, Y., 2004. Podzolization as a deferralitization process: a study of an Acrisol-Podzol sequence derived from Palaeozoic sandstones in the northern upperAmazon Basin. Eur. J. Soil Sci. 55, 523-538.

Dolbec, J., Mergler, D., Sousa Passos, C. J., Sousa de Morais, S., Lebel, J., 2000. Methylmercury exposure affects motor performance of a riverine population of the Tapajos river, Brazilian Amazon. Interna. Arch. Occup. Environ. Health 73, 195-203.

Dominique, Y., Muresan, B., Duran, R., Richard, S., Boudou, A., 2007. Simulation of the Chemical Fate and Bioavailability of Liquid Elemental Mercury Drops from Gold Mining in Amazonian Freshwater Systems. Environ. Sci. Tech. 41, 7322 7329.

Egal, E., Milési, J. P., Ledru, P., Cautru, J. P., Freyssinet, P., Thiéblemont, D., Vernhet, Y., 1994. Mineralogical resources and lithostructural evolution of French Guiana. 1/100 000 thematic map. Cayenne sheet. Mining Geol. Res. Bureau report (BRGM) R 38019 (in French).

Feyte, S. Distribution of total mercury and methylmercury in sediments and sediment porewater of two contrasted basins of the same lake In: University WL, editor. $21^{\text {st }}$ Annual Gananoque "Environmental Sciences and Engineering". Wilfrid Laurier University, Gananoque, Ontario, 2007, pp. 29.

Fitzgerald, W. F., Lamborg, C. H., 2003. Geochemistry of mercury in the environment. In: Sherwood Lollar B, ed, Treatise on Geochemistry. 9. Elsevier, pp. $107-148$

Fleming, E. J., Mack, E. E., Green, P. G., Douglas, C. N., 2006. Mercury methylation from unexpected sources :molybdate-inhibited freshwater sediments and ironreducing bacterium. Appl. Environ. Microbiol. 72, 457-464.

Frery, N., Maury-Brachet, R., Maillot, E., Deheeger, M., Merona de, B., Boudou, A., 2001. Goldmining activities and mercury contamination of native Amerindian communities in french Guiana: key role of fish in dietary uptake. Environ. Health Persp. 109, 449-456.

Gray, J., Hines, M., Higueras, P., Adatto, I., Lasorsa, B., 2004. Mercury speciation and microbial transformations in mine wastes, stream sediments, and surface waters at the Almadén mining district, Spain. Environ. Sci. Technol. 38, 42854292.

Gray, J. E., Hines, M. E., Biester, H., 2006. Mercury methylation influenced by areas of past mercury mining in the Terlingua district, Southwest Texas, USA. Appl. Geochem. 21, 1940-1954.

Guedron, S., Grangeons, S., Lanson, B., Grimaldi, M., 2009. Mercury speciation in a tropical soil association; Consequence of gold mining on $\mathrm{Hg}$ distribution in French Guiana. Geoderma 153, 331-346.

Guedron, S., Grimaldi, C., Chauvel, C., Spadini, C., Grimaldi, M., 2006. Weathering versus atmospheric contributions to mercury concentrations in French Guiana soils. Appl. Geochem. 21, 2010-2022.

Guimaraes, J. R. D., Meili, M., Hylander, L. D., Silva, E. d. C., Roulet, M., Mauro, J. B. N., de Lemos, R. A., 2000a. Mercury net methylation in five tropical flood 
plain regions of Brazil: high in the root zone of floating macrophyte mats but low in surface sediments and flooded soils. Sci. Total Environ. 261, 99-107.

Guimaraes, J. R. D., Roulet, M., Lucotte, M., Mergler, D., 2000b. Mercury methylation along a lake-forest transect in the Tapajos river floodplain, Brazilian Amazon: seasonal and vertical variation. Sci. Tot. Environ. 261, 91-98.

Hind, A. R., Bhargava, S. K., Grocott, S. C., 1999. The surface chemistry of Bayer process solids: a review. Colloids and Surfaces A: Physicochemical and Engineering Aspects 146, 359-374.

Ikingura, J. R., Akagi, H., Mujumba, J., Messo, C., 2006. Environmental assessment of mercury dispersion, transformation and bioavailability in the Lake Victoria Goldfields, Tanzania. J. Environ. Manag. 81, 167-173.

Jezequel, D., Brayner, R., Metzger, E., Viollier, E., Prevot, F., Fievet, F., 2007. Twodimensional determination of dissolved iron and sulfur species in marine sediment pore-waters by thin-film based imaging. Thau lagoon (France). Estuarine Coastal Shelf Sci. 72, 420-431.

Kehrig, H. A., Pinto, F. N., Moreira, I., Malm, O., 2003. Heavy metals and methylmercury in a tropical coastal estuary and a mangrove in Brazil. Org. Geochem. 34, 661-669.

Lacerda, L. D., 1997. Global mercury emissions from gold and silver mining. Water Air Soil Poll. 97.

Lacerda, L. D., Salomons, W., 1998. Mercury from Gold and Silver Mining: A Chemical Time Bomb? Springer-Verlag Berlin.

Lamborg, C. H., Yigiterhan, O., Fitzgerald, W. F., Balcom, P. H., Hammerschmidt, C. R., Murray, J., 2008. Vertical distribution of mercury species at two sites in the Western Black Sea. Mar. Chem. 111, 77-89.

Lin, C. C., Jay, J. A., 2007. Mercury methylation by planktonic and biofilm cultures of Desulfovibrio desulfuricans. Environ. Sci. Technol. 41, 6691-6697.

Muresan, B. Mercury geochemistry in the continuum of Petit Saut reservoir and the Sinnamary estuary, French Guiana (in French). University of Bordeaux I, PhD Thesis, 2006, pp. 264.

Muresan, B., Cossa, D., Jezequel, D., Prevot, F., Kerbellec, S., 2007. The biogeochemistry of mercury at the sediment-water interface in the Thau lagoon. 1. Partition and speciation. Estuarine Coastal Shelf Sci. 72, 472-484.

Muresan, B., Cossa, D., Richard, S., Dominique, Y., 2008. Monomethylmercury sources in a tropical artificial reservoir. Appl. Geochem. 23, 1101-1126.

Pfeiffer, W. C., Lacerda, L. D., Salomon, W., Malm, O., 1993. Environmental fate of mercury from gold mining in the brazilian Amazon. Environ. Rev. 1, 26-37.

Roulet, M., Guimaraes, J. R. D., Lucotte, M., 2001a. Methylmercury production and accumulation in sediments and soils of an amazonian floodplain - Effect of seasonal inundation. Water Air Soil Poll. 128, 41-60.

Roulet, M., Lucotte, M., 1995. Geochemistry of mercury in pristine and flooded ferralitic soil of a tropical rain forest in French Guiana, South America. Water, Air, Soil Poll. 80, 1079-1088.

Roulet, M., Lucotte, M., Canuel, R., Farella, N., Freitos Goch, Y. G. D., Pacheco Peleja, J. R., Guimaraes, J.-R. D., Mergler, D., Amorim, M., 2001b. SpatioTemporal Geochemistry of Mercury in Waters of the Tapajos and Amazon Rivers, Brazil. Limnol. Oceanogr. 46, 1141-1157.

Schimann, H., Joffre, R., Roggy, J.-C., Lensi, R., Domenach, A.-M., 2007. Evaluation of the recovery of microbial functions during soil restoration using near-infrared spectroscopy. Appl. Soil Ecol. 37, 223-232. 
Schroeder, W. H., Munthe, J., 1998. Atmospheric mercury - An overview. Atmos. Environ. 32, 809-822.

Schwertmann, U., Cornell, R. M., 2000. Iron oxides in the laboratory : preparation and characterization. Wiley- $\mathrm{VCH}$ Weinheim.

Smodis, B., 2006. Mercury cycling in contaminated tropical non-marine ecosystems. J. Environ. Manag. 81, 93-94.

Sunderland, E. M., Krabbenhoft, D. P., Moreau, J. W., Strode, S. A., Landing, W. M., 2009. Mercury sources, distribution, and bioavailability in the North Pacific Ocean: Insights from data and models. Global Biogeochem. Cycles 23.

Tseng, C. M., de Diego, A., Pinaly, H., Amouroux, D., Donard, O. F. X., 1998. Cryofocusing coupled to atomic absorption spectrometry for rapid and simple mercury speciation in environmental matrices. J. Anal Atom Spectro. 13, 755764.

Ullrich, S. M., Tanton, T. W., Abdrashitova, S. A., 2001. Mercury in the aquatic environment: A review of factors affecting methylation. Crit. rev. Environ. Sci. Technol. 31, 241-293.

Veiga, M. M., Hinton, J., Lilly, C. mercury in the Amazon: a comprehensive review with special emphasis on bioaccumulation and bioindicator. Proc. National Institute for Minamate disease, Minamata, Japon, 1999, pp. 19-39.

Watras, C., 1992. Mercury and methylmercury in individual zooplankton: implications for bioaccumulation. Limnol. Oceanogr. 37, 1313-1318.

Watras, C. J., Bloom, N. S., Hudson, R. J. M., Gherini, S., Munson, R., Claas, S. A., Morrison, K. A., Hurley, J., Wiener, J. G., Fitzgerald, W. F., et al., 1994. Sources and Fates of mercury and methylmercury in Wisconsin lakes, Mercury pollution: integration and synthesis, pp. 153-177

Winch, S., Praharaj, T., Fortin, D., Lean, D. R. S., 2008. Factors affecting methylmercury distribution in surficial, acidic, base-metal mine tailings. Sci. Tot. Environ. 392, 242-251. 
Figure 1. French Guiana map and location of the studied gold mine sites.

\section{Figure captions}

Figure 2. Field observations. Vertical profiles of dissolved monomethylmercury $\left((\mathrm{MMHg})_{\mathrm{D}}\right)$, redox potential $(\mathrm{Eh})$ and reduced iron $\left(\mathrm{Fe}^{\mathrm{I}}\right)$ in water column and in sediment pore water of Combat (dark triangles) and Yaoni (dark squared) decantation basins, sulfide-accumulating zone (SAZ, grey color) and sediment-water interface $(0 \mathrm{~cm})$.

Figure 3. Laboratory experiments. $\mathrm{pH}$ and conductivity changes with time in oxic compartments with slake lime addition (F1O and F2O) and oxic control compartments ( $\mathrm{C} 1 \mathrm{O}$ and $\mathrm{C} 2 \mathrm{O})$ without flocculant.

Figure 4. Laboratory experiments. Vertical profiles of dissolved monomethylmercury $\left((\mathrm{MMHg})_{\mathrm{D}}\right)$, redox potential $(\mathrm{Eh})$ and reduced iron $\left(\mathrm{Fe} \mathrm{e}^{\mathrm{Il}}\right)$ in water column and in sediments pore water of anoxic compartments with slake lime addition (F1A: dark diamonds and F2A: dark x-hair diamonds).

Figure 5. Laboratory experiments. Vertical profiles of dissolved monomethylmercury $\left((\mathrm{MMHg})_{\mathrm{D}}\right)$, redox potential $(\mathrm{Eh})$ and reduced iron $\left(F e^{\prime \prime}\right)$ in water column and in sediments pore water of open air compartments with slake lime addition (F1O: white diamonds and F2O: $\mathrm{x}$ hair diamonds) and open air control compartments (C1O: white circles and C2O: $x$-hair white circles) without slake lime. 
611

612

613

Fig. 1.

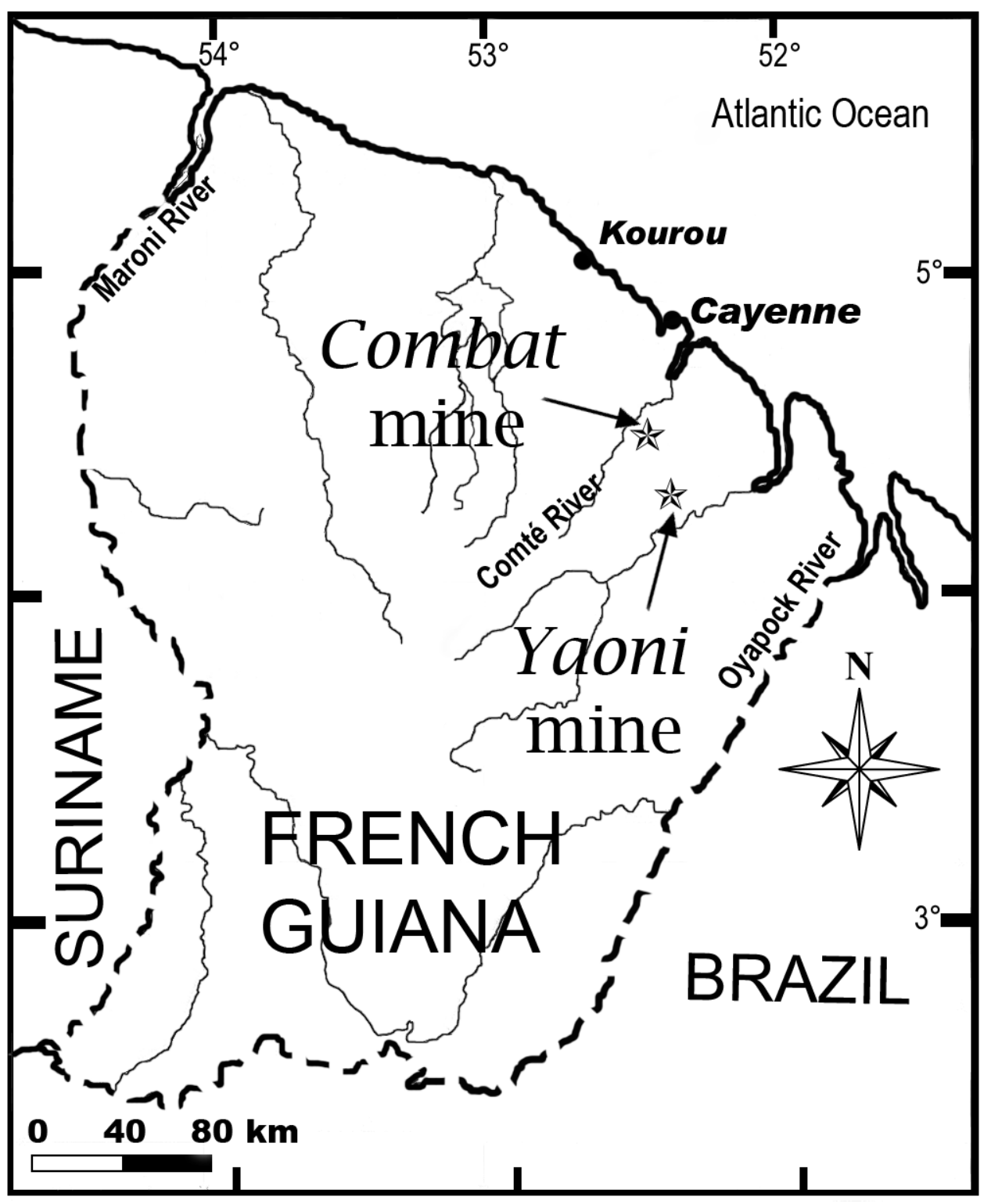


Fig. 2.

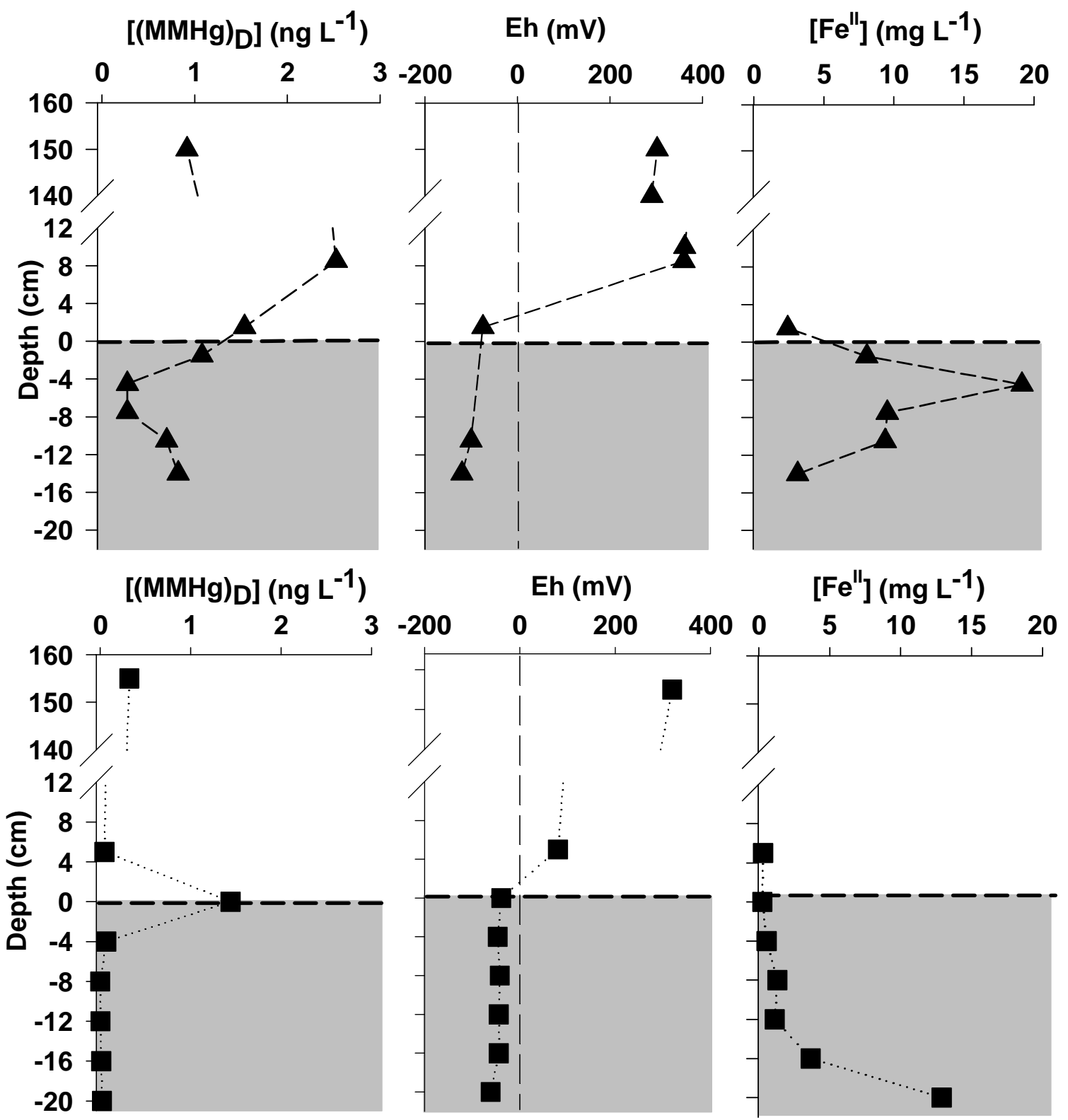


626

627

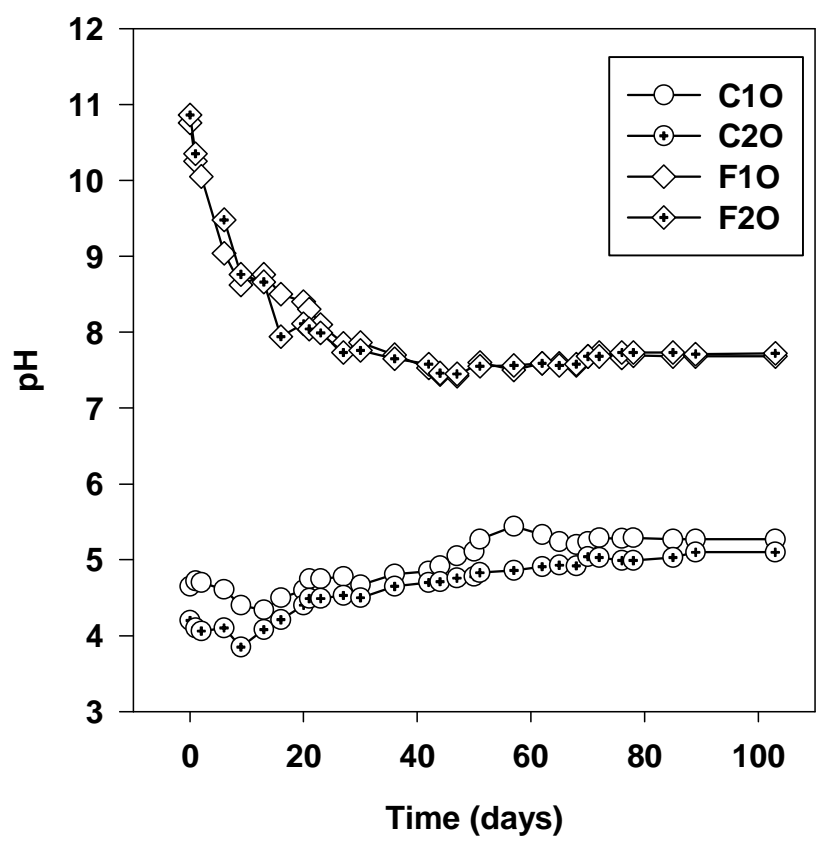

Fig. 3.

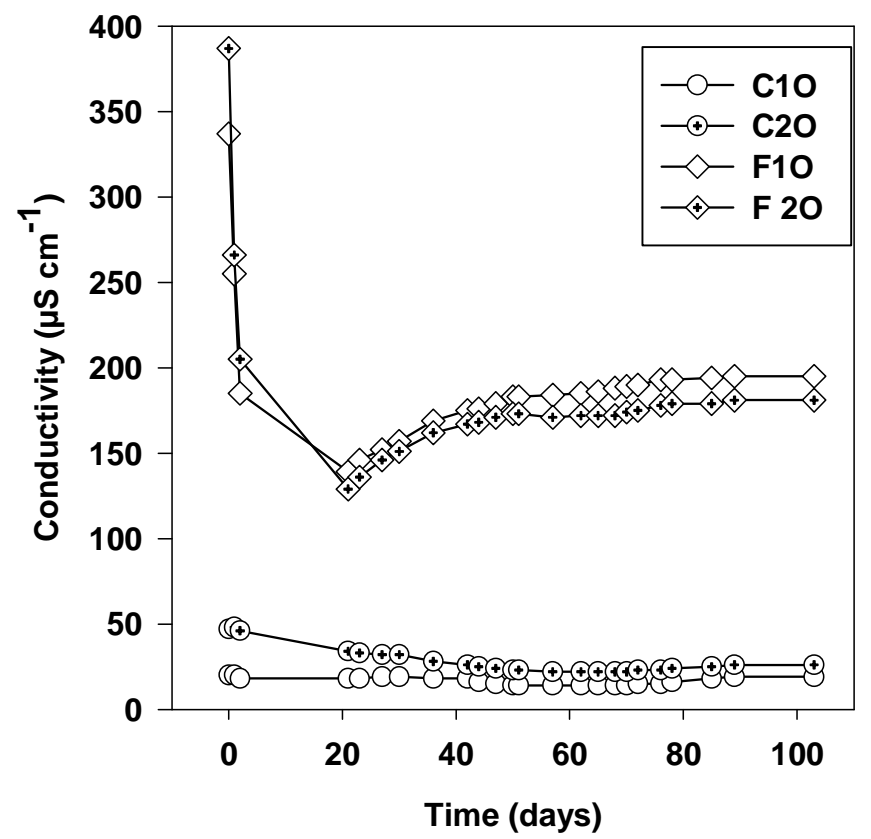

630

631 
632 Fig. 4.

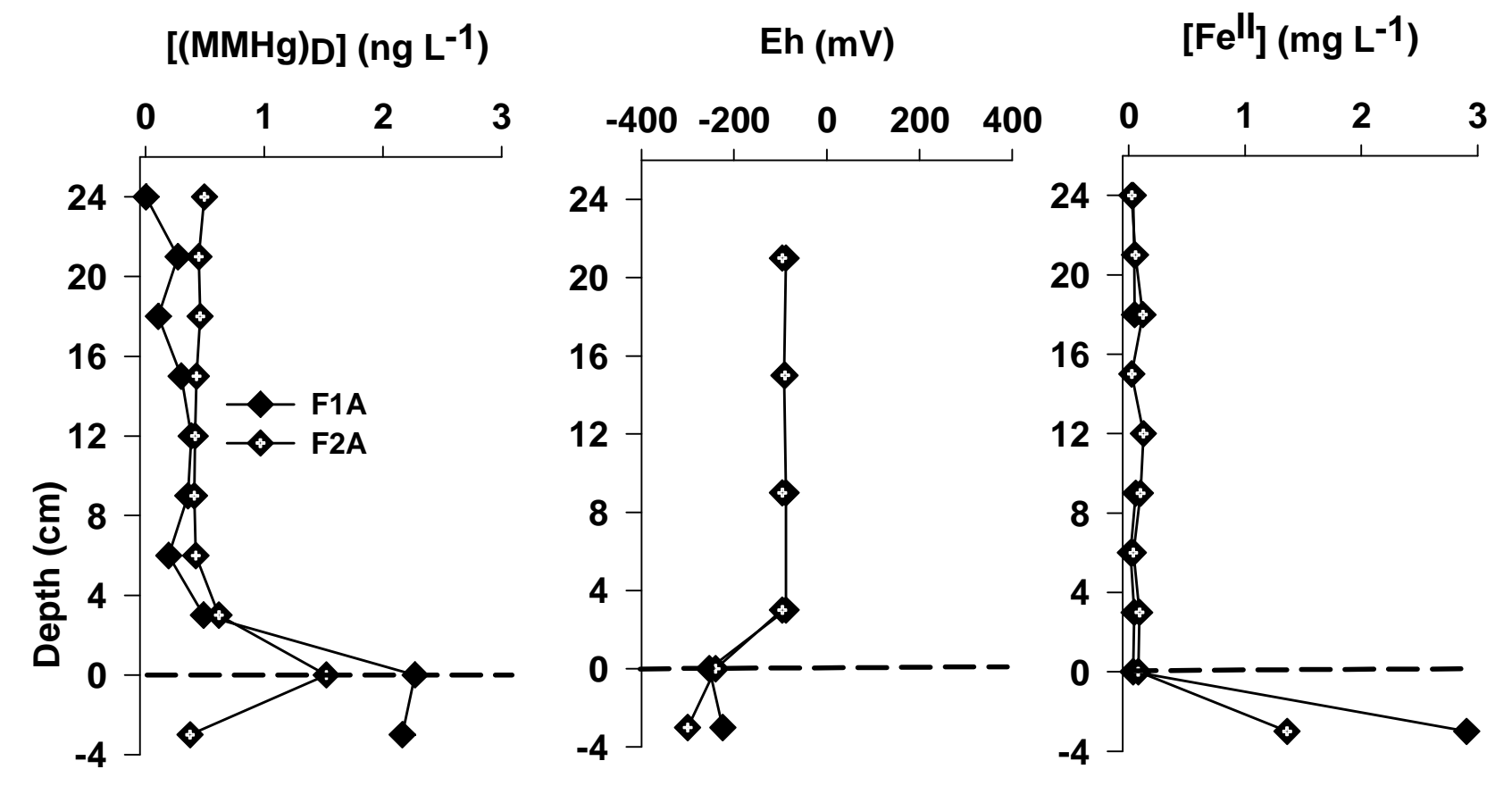


638

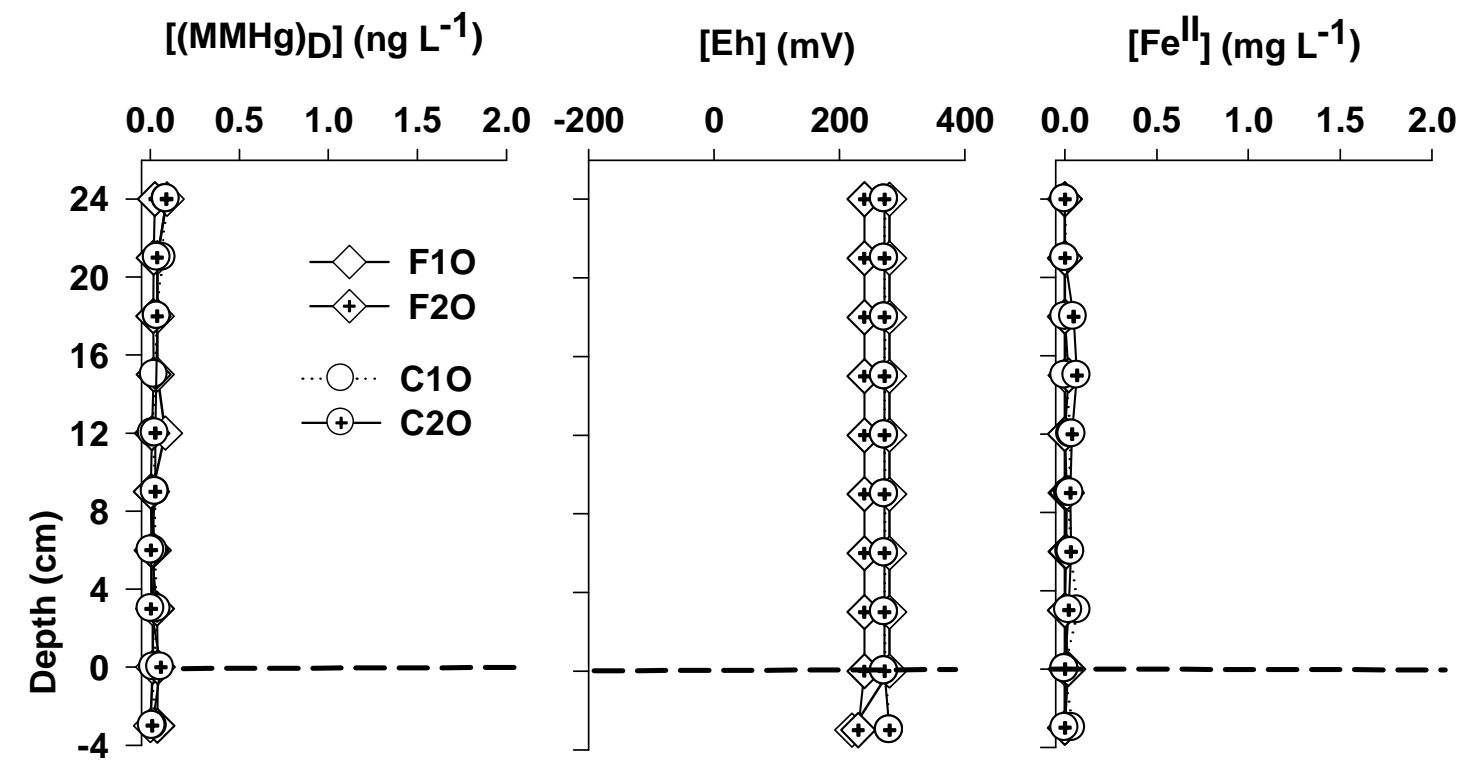

Fig. 5.

639 